\title{
JAN PAWEL II A 1600. ROCZNICA ŚMIERCI ŚW. CYRYLA JEROZOLIMSKIEGO
}

List Apostolski Omnium Ecclesiarum Matri ${ }^{1}$ Ojca Świętego Jana Pawła II z okazji 1600. rocznicy śmierci św. Cyryla Jerozolimskiego nosi datę 7 marca 1987 roku. Wskazuje ona, że papież opowiada się za rozstrzygnięciem daty śmierci tego Ojca Kościoła na rok 387. Wprawdzie zaznacza w tekście, że ,[...] zbliża się dzień, w którym prawdopodobnie przypada 1600. rocznica śmierci tego świętego Doktora Kościoła"2, jednakże wydaje się, że analiza daty śmierci Cyryla, dokonana przez P. Nautina uznana została przez Autora Listu za wystarczającą ${ }^{3}$. Potwierdzenie tego znajdujemy w dalszej części Listu, w której Jan Paweł II zwraca uwagę na zbieżność daty śmierci Cyryla Jerozolimskiego z datą chrztu Augustyna. Wymienia przy tej okazji obie daty: 18 marca 387 i 24 kwietnia 387, zwracając przy tym uwagę na to, że wspólne dla obu Ojców Kościoła jest spojrzenie na grzech jako wielkie zło, jak również na miłosierdzie Boże jako nieogarniony skarb.

Bezpośrednim adresatem Listu Apostolskiego jest łaciński patriarcha Jerozolimy Jakub Józef Beltritti. Biorąc pod uwagę nie tylko początek Listu, ale także jego zakończenie, trudno nie odnieść wrażenia, że dla Jana Pawła II rocznica śmierci Cyryla Jerozolimskiego stanowi przede wszystkim okazję do bezpośredniego zwrócenia się do Kościoła w Jerozolimie, który nazywa „Matką wszystkich Kościołów”. Cyryla uważa papież za szczególny dar dla Kościoła Jerozolimskiego i czołową jego postać. Jan Paweł II podkreśla z naciskiem, że całe życie Cyryla było związane z Jerozolimą. Z tej racji przytacza pewne szczegóły z jego życia: przypomina m.in., że całe dzieciństwo i młodość tego Ojca Kościoła były związane z Jerozolimą, przywołując zaś katechezę XII

${ }^{1}$ Por. Epistola Apostolica „Omnium Ecclesiarum Matri”, OsRom 127 (1987) nr 73, s. 1-5, tłum. S. Longosz, VoxP 10 (1990) z. 18, 41-44.

${ }^{2}$ Tamże, VoxP z. 18, s. 42.

3 Por. P. Nautin, La date du „De viris illustribus” de Jérome, de la morte de Cyrille de Jérusalem et de celle de Grégoire de Nazianze, RHE 56 (1961) 33-35. Autor jako datę śmierci Cyryla podaje 18 marca 387 roku. Takie dane zawarte są także w podręcznikach patrologii B. Altanera i J. Quastena, natomiast M. Starowieyski (SWP 113) jako rok śmierci podaje 386 rok. 
wnioskuje, że przed przyjęciem biskupstwa prowadził on jakąś formę życia zakonnego ${ }^{4}$.

Z kolei Jan Paweł II wskazuje na ważniejsze wydarzenia z życia Cyryla jako biskupa. Dyskretnie ustosunkowuje się do sprawy udzielenia sakry biskupiej przez Akacjusza, metropolitę Cezarei Palestyńskiej, znanego ze swego zaangażowania proariańskiego. Powołując się na fakt kilkakrotnego wygnania Biskupa Jerozolimy właśnie z podpuszczenia Akacjusza, papież stwierdza, że Cyryl jest wolny od jakichkolwiek podejrzeń o powiązania doktrynalne z błędnowiercami. W ten sposób Ojciec Święty opowiada się po stronie tych badaczy, którzy podważają wiarygodność sugestii zawartych u Sokratesa ${ }^{5}$ i Sozomena ${ }^{6}$ jakoby Cyryl sprzyjał arianizmowi, a przyjmuje świadectwo Teodereta z Cyru ${ }^{7}$ i cytowanego przez niego listu synodalnego Soboru Konstantynopolitańskiego do papieża Damazego z 382 roku $^{8}$. Należy w tym miejscu zauważyć, że Jan Paweł II pisząc o Cyrylu: „musiał kilkakrotnie iść na wygnanie"9 , chciał przypomnieć trzykrotne usunięcie Ojca Kościoła z Jerozolimy, które było rezultatem konfliktu z Akacjuszem i arianizmem, a także nieugiętej obrony przez niego symbolu nicejskiego. Pierwsze z wygnań miało miejsce w 357 r., kiedy to Cyryl schronił się u biskupa Tarsu Sylwana. Przywrócony na stolicę biskupią dekretem synodu w Seleucji, wkrótce potem (w 360 r.) ponownie musiał opuścić Jerozolimę na skutek intryg Akacjusza. Po dwóch latach wrócił znowu do Świętego Miasta dzięki cesarzowi Julianowi, lecz już w 367 r., mimo że Akacjusz już nie żył († 366), został złożony z urzędu przez cesarza Walensa i to wygnanie trwało najdłużej, bo do 378 r., czyli do śmierci cesarza.

Jan Paweł II odnotowuje także ważne wydarzenie z życia Cyryla po jego powrocie z trzeciego wygnania, jakim jest udział w I Soborze Konstantynopolitańskim w 381 roku. Mimo że fakty biograficzne zostały potraktowane w omawianym dokumencie bardzo skrótowo, czy wręcz hasłowo, to jednak papież w końcowej części Listu przytacza jeszcze jeden epizod z życia tego Ojca Kościoła. Jest nim niezwykłe zjawisko ukazania się na niebie wielkiego świetlanego krzyża, rozpiętego między Golgotą a Górą Oliwną, które miało mieć miejsce w maju 351 r. i było widziane przez wielu mieszkańców Jerozolimy, w tym także przez Cyryla. Sam Cyryl opisuje to wydarzenie w Liście do

${ }^{4}$ Por. Catechesis XII 33, PSP 9, 171: „Niech poznają dziewice Tego, który jest koroną ich życia! Niech pozna zastęp mnichów Tego, który jest chlubą ich czystości! [...]. Jeśli zatem Panna chlubi się dziewięciu miesiącami, my mężczyźni jeszcze bardziej możemy się chlubić o wiele dłuższym czasem".

5 Por. HE II 38.

${ }^{6}$ Por. HE IV 20.

7 Por. HE II 22.

${ }^{8}$ Por. HE V 6.

9 Omnium Ecclesiarum Matri, VoxP z. 18, s. 42. 
Cesarza Konstancjusza $a^{10}$. Jan Paweł II wykorzystuje ten fakt do skierowania zachęty pod adresem mieszkańców Ziemi Świętej o zgodę i pokój.

Istotne znaczenie dla właściwej oceny Cyryla Jerozolimskiego i jego doktryny widzi Jan Paweł II, w nadaniu w 1883 r. temu Ojcu Kościoła przez papieża Leona XIII tytułu „Doktora Kościoła”. Tytuł ten stanowi punkt wyjścia do wyliczenia zasług Cyryla. Na pierwszym miejscu Ojciec Święty wskazuje na niego, jako na świadka apostolskiej wiary. Na drugim miejscu dostrzega w nim przede wszystkim pasterza, który cechuje się zatroskaniem o sakramentalne i liturgiczne objaśnienie wiary; dla realizacji tego celu Cyryl posługiwał się chrzcielnym symbolem wiary, znanym w Kościele Jerozolimskim, który szczegółowo objaśniał. Papież - z pewną predylekcją - zwraca uwagę na to, że swoje katechezy Biskup Jerozolimy głosił w miejscach związanych bezpośrednio z tajemnicą paschalną, którymi były Kalwaria, Grób Święty i Anastasis.

Z kolei Jan Paweł II przechodzi do zaprezentowania wiodących tematów katechez Cyryla, do których zalicza:

1. grzech i jego źródła,

2. kuszenie szatana,

3. potrzeba pokuty,

4. moc Ducha Świętego w sakramencie chrztu.

Papież nie komentuje tych tematów, lecz zwraca uwagę na to, że w nauczaniu Augustyna można znaleźć ich paradygmat.

Osobne miejsce poświęca Autor Listu metodzie katechez głoszonych przez tego Ojca Kościoła, zauważając, że mają one dużą siłę przekonywania: z jednej strony są nasycone Pismem Świętym, z drugiej zaś nie brak w nich obrazów zaczerpniętych z natury. Uderza w nich także odczuwalna „świeżość początków”. To predysponuje je do uznania ich za jedne z najcenniejszych pereł greckiej literatury patrystycznej. Ich ponadczasowy walor wynika z niezwykle dynamicznego objaśnienia piękna i skuteczności rytów.

Przedmiot katechez Cyryla odróżniony w Liście od tematów wiodących, zajmuje w dokumencie niewiele miejsca. Jan Paweł II ogranicza się do stwierdzenia, że obejmuje on najważniejsze części pierwotnej nauki wiary, które grupuje w sześciu punktach:

1. tajemnica Trójcy Świętej,

2. bóstwo wcielonego Słowa,

3. dziewicze narodzenie,

4. niezniszczalna pieczęć Ducha Świętego,

5. Eucharystia - obecność i ofiara,

6. konsekracyjna moc epiklezy.

${ }^{10}$ Por. Epistula ad Constantium imperatorem, PG 33, 1165-1176, thum. W. Kania, VoxP 6 (1986) z. 10, 285-296. 
Papież nie wskazuje, które z wymienionych zagadnień ma szczególne znaczenie dla teologii patrystycznej, lecz zwraca uwagę na ich aktualność dla ludzi naszej epoki. Stwierdza ogólnie, że są one nadal ,pokarmem i źródłem światła” nie tylko dla wierzących, ale także dla tych, którzy mają „duszę otwartą na Ewangelię"11. Nie zostało więc w Liście wyeksponowane nauczanie Cyryla na temat epiklezy konsekracyjnej, które - jak się wydaje - ma zasadnicze znaczenie, zarówno dla teologii liturgii jak i dla całego kontekstu doktryny patrystycznej. Nauczanie Biskupa Jerozolimy o roli Ducha Świętego w akcie przemiany eucharystycznej jest bowiem nie tylko świadectwem wiary i tradycji liturgicznej Kościoła pierwszych wieków, ale - co może ważniejsze - stało się wektorem nauczania późniejszych pisarzy o obecności i działaniu Ducha Świętego w Eucharystii. Nauczanie to - jak wiadomo - pozostało żywe poprzez wieki w duchowości Kościołów Wschodnich.

W zakończeniu Listu Jan Paweł II wyraża gorące pragnienie, aby tam, gdzie Cyryl pełnił „długą i udręczoną posługę w służbie prawdy, jedności i miłości" powróciła nadzieja zgody i pokoju ${ }^{12}$. Sama zaś rocznica winna uzmysłowić całemu Kościołowi, że Jezus Chrystus jest ciągle niewyczerpanym źródłem obfitości życia, co stanowi istotne przesłanie katechez, które przed 1600 laty głosił Cyryl właśnie w Jerozolimie.

Podsumowując całą treść omawianego Listu Apostolskiego można próbować określić motywy, którymi kierował się Jan Paweł II przy jego pisaniu. Wydaje się - jak to już wyżej zostało powiedziane - że sama rocznica śmierci Cyryla Jerozolimskiego była raczej pretekstem do tego, by Biskup Rzymu mógł w takiej właśnie uroczystej formie zwrócić się do Biskupa Jerozolimy. Kościół w Ziemi Świętej był - jak wiadomo - przedmiotem szczególnej troski Jana Pawła II i znajdował wyjątkowe miejsce w jego sercu. Znalazło to swój wyraz m.in. w jego pielgrzymce do Ziemi Świętej. Tym też należałoby tłumaczyć fakt, że Jan Paweł II skoncentrował się w Liście głównie na uniwersalnym wymiarze nauczania Biskupa Jerozolimy sprzed 1600 lat. Takie ujęcie pozwala wyraziściej dostrzec absolutną spójność i tożsamość nauczania w Kościele zarówno w wymiarze czasowym jak i przestrzennym. Wymiar czasowy to ukazana przez Papieża aktualność nauczania Cyryla Jerozolimskiego w dzisiejszych czasach, i to nie tylko dla wierzących. Wymiar przestrzenny to przejęcie bez zastrzeżeń nauczania Katechety z Jerozolimy w całym Kościele, zarówno na Wschodzie jak i na Zachodzie. Uderzająca staje się zgodność Kościołów chrześcijańskich w recepcji doktryny Cyryla, która właściwie obejmuje pełny wykład wiary chrześcijańskiej, oparty na solidnej trynitologii, chrystologii, pneumatologii, sakramentologii i eklezjologii. Tematy teologiczne w jego ujęciu, wypunktowane przez Papieża, mogą stanowić bazę zgodnego, wolnego od napięć naro-

${ }^{11}$ Por. Omnium Ecclesiarum Matri, VoxP z. 18, s. 44.

12 Por. tamże. 
słych w późniejszych wiekach dialogu międzywyznaniowego. W tym sensie List Apostolski Omnium Ecclesiarum Matri Ojca Świętego Jana Pawła II z okazji 1600. rocznicy śmierci św. Cyryla Jerozolimskiego stanowi cenny i - jak się wydaje - nie w pełni wykorzystany dokument ukierunkowujący, a raczej wskazujący drogę, która może doprowadzić do jedności wszystkich chrześcijan.

\section{JEAN PAUL II ET 1600 ANNIVERSAIRE DE LA MORT DE SAINT CYRILLE DE JÉRUSALEM}

(Résumé)

Dans cet article nous sommes référé à l'épître de Jean Paul II à l'occasion de 1600 anniversaire de la mort de saint Cyrille de Jérusalem. Au début le pape écrit de la vie de saint Cyrille et suivant il présente ses mérites, qui ont décidé pour apporter à ce Saint le titre: „Docteur de l'Église”. En suite Jean Paul II énumère les thèmes principales dans les Catéchèses du saint Cyrille, même leur méthode et leur contenu. À la fin le pape exprime son désir de revenir à l'espérance de la concorde et de la paix dans le pays, ou saint Cyrille a passé sa vie. 